\title{
Peningkatan Kemampuan Representasi Matematis Siswa MI Kota Bengkulu melalui Pembelajaran CMP
}

\author{
M. Syahdi \\ Pangawas RA/MI, Kantor Kementerian Agama Kota Bengkulu \\ m.syahdi@gmail.com
}

\begin{abstract}
This study aims to determine the improvement of the mathematical representation ability of Bengkulu City MI students through CMP Learning. This type of research is quasy experimental with a quantitative approach. The population of this study were students of Class IV MI of Bengkulu City with the techniques used for sampling were intact groups. In this study the IVE class was an experimental class or a class that was given CMP treatment and as a control class was Class IVC, which was a class given direct learning treatment. The instrument of this research is a test of mathematical representation ability. The data obtained were analyzed using anacova. The results showed that there was a significant increase in the ability of mathematical representation to learn using CMP learning. The increase in the ability of mathematical representations that learn to use CMP learning is higher than students who get regular learning.
\end{abstract}

Keywords: CMP Learning, Mathematical Representation

\begin{abstract}
Abstrak
Penelitian ini bertujuan untuk mengetahui peningkatan kemampuan Representasi Matematis siswa MI Kota Bengkulu melalui Pembelajaran CMP. Jenis penelitian ini quasy experimental dengan pendekatan kuantitatif. Populasi dari penelitian ini adalah siswa Kelas IV MI Kota Bengkulu dengan teknik yang digunakan untuk pengambilan sampel adalah intact group. Pada penelitian ini Kelas IVE merupakan kelas eksperimen atau kelas yang diberi perlakuan CMP dan sebagai kelas kontrol adalah Kelas IVC, yaitu kelas yang diberi perlakuan pembelajaran langsung. Instrumen penelitian ini adalah tes kemampuan representasi matematis. Data yang diperoleh dianalisis dengan menggunakan anacova. Hasil penelitian menunjukkan terdapat peningkatan yang signifikan kemampuan representasi matematis yang belajar menggunakan pembelajaran CMP. Peningkatan kemampuan representasi matematis yang belajar menggunakan pembelajaran CMP lebih tinggi dari siswa yang mendapat pembelajaran biasa.
\end{abstract}

\section{Kata kunci : Pembelajaran CMP, Representasi Matematis}

\section{Pendahuluan}

Pada era industri 3.0, pendidikan dengan memanfaatkan literasi data besar (big data) merupakan salah satu aktivitas utama dalam pembelajaran matematika. Karena matematika merupakan aktivitas manusia (Fauzan, Slettenhaar, \& Plomp, 2002) (Wahyu Widada et al., 2019), sehingga pembelajaran matematika harus dimulai dari hal-hal yang dekat dengan pikiran dan budaya di lingkungannya 
(etnomatematika) (Ubiratan D'ambrosio, 1985)(Wahyu Widada et al., 2019). Sedemikian hingga siswa dapat mengonstruksi keterkaitan aksi-proses-objek sehingga terbentuk skema bagian dari skema yang matang (premature schema). Dalam pembentukan premature schema tersebut ada kemungkinan seseorang tersebut menggunakan skema awal (melakukan retrieval of the previous schema) (Wahyu Widada, 2016b)(Wahyu Widada, 2016a)(Wahyu Widada, Herawaty, Yanti, \& Izzawati, 2018).

Berdasarkan (Dewi Herawaty \& Rusdi, 2016), kemampuan Kemampuan Representasi Matematis konsep dan pemecahan masalah kelas yang diberi pembelajaran pendekatan matematika realistik lebih baik dibandingkan kelas kontrol yang diberi pembelajaran matematika konvensional. Peningkatan kemampuan Kemampuan Representasi Matematis konsep melalui penerapan model pembelajaran matematika berdasarkan konflik kognitif siswa adalah signifikan dengan indeks gain sebesar 0,755 (level tinggi). Peningkatan kemampuan pemecahan masalah melalui penerapan model pembelajaran matematika berdasarkankonflik kognitif siswa SMP Kota Bengkulu adalah signifikan dengan indeks gain sebesar 0,500 (level sedang). Hal ini menandakan bahwa pembelajaran matematika yang dekat dengan pikiran siswa dapat meningkatkan kemampuan matematikanya.

Budaya yang ada di lingkungan siswa belajar matematika akan menjadi inspirasi siswa untuk merepresentasikan konsep dan prinsip matematika. Oleh karena itu, pembelajaran dengan pendekatan etnomatematika (D. Herawaty, Widada, Novita, Waroka, \& Lubis, 2018)(W. Widada, Herawaty, \& Lubis, 2018) menjadi suatu yang diperlukan bagi siswa. Ini merupakan suatu pendekatan pembelajaran matematika yang mengaitkan dunia sekitar sebagai awal mula pembelajaran matematika. Dalam hal ini connected mathematics project (Lappan et al., 2002)(Phillips, 2003)(Eddy \& Berry, 2008).

Urutan pembelajaran haruslah menghadirkan suatu aktivitas atau eksplorasi, yaitu siswa menciptakan dan mengelaborasi model-model simbolik dan aktivitas matematika mereka yang tidak formal, misalnya menggambar, membuat diagram membuat tabel atau mengembangkan notasi informal (Wahyu Widada, 2004). Pembelajaran matematika tidak semata-mata memberi penekanan pada komputasi dan hanya mementingkan langkah-langkah prosedural atau algoritma serta keterampilan, namun memberi penekanan pada Kemampuan Representasi Matematis konsep dan pemecahan masalah (Lappan et al., 2002)(Wahyu Widada, 2004). Siswa mengalami proses pembelajaran secara bermakna dan memahami matematika dengan penalaran. Siswa belajar matematika dengan Kemampuan Representasi Matematis, secara aktif membangun pengetahuan baru dari pengalaman dan pengetahuan awal. Dalam pembelajaran siswa dilatih untuk mengikuti pola kerja, intuisi-coba-salah-dugaan/spekulasi-hasil. Selain itu terdapat interaksi yang kuat antara siswa dengan siswa lainnya, dan memberikan perhatian seimbang antara matematisasi horisontal dan vertical (Zulkardi, 1999)(Gravemeijer, 2008)(Gravemeijer, 2008)(Wahyu Widada, 2004).

Kemampuan representasi matematika merupakan hal yang sangat penting dan perlu ditingkatkan dalam pembelajaran matematika karena komunikasi bisa membantu pembelajaran siswa tentng konsep matematika ketika mereka 
memerankan situasi, menggambar, menggunakan objek, memberikan laporan dan penjelasan verbal.

Baroody (dalam Ansarim 2009) menyebutkan sedikitnya ada dua alasan

Berdasarkan latar belakang masalah diatas maka dapat disimpulkan permasalahan sebagai berikut: Apakah terdapat pengaruh langsung pembelajaran Connected Mathematics Project terhadap kemampuan Representasi Matematis siswa MI Kota Bengkulu?

\section{Metode Penelitian}

Berdasarkan tujuan penelitian, maka penelitian ini adalah penelitian eksperimen. Karena saat perlakukan tidak memungkinkan untuk mengontrol atau memanipulasi semua variabel yang berpeluang mempengaruhi hasil perlakuan, maka jenis penelitian ini adalah eksperimen semu. Populasi penelitian adalah siswa Kelas IV MI Kota Bengkulu. Sampel dipilih dengan intact group yaitu satu kelas yang dikenei perlakukan dengan pembelajaran CMP dan satu kelas lainnya sebagai kelas Kontrol (sebutlah yaitu Kelas IV E sebagai kelas eksperimen dan Kelas IV C sebagai kelas control). Instrumen penelitian ini adalah tes kemampuan representasi matematis. Data hasil tes kemampuan tersebut dianalisis dengan analisis kovariat.

\section{Hasil dan Pembahasan}

Sebelum perlakukan siswa diberi pretest kemampuan representasi matematis yang bertujuan untuk mengetahui kemampuan awal siswa. Perlakukan diberikan selama 4 (empat) pekan dengan menggunakan empat Rencana Pelaksanaan Pembelajaran (RPP). Sepekan setelah perlakukan selesai, siswa diberikan posttest. Hasil pretes-postest lihat Tabel 3.1.

Table 3.1 Hasil pretest- posttest Kemampuan Representasi Matematis

\begin{tabular}{|c|c|c|c|c|c|c|c|}
\hline Kelas & Jumlah & Rata-rata & Rata-rata & \multicolumn{2}{|c|}{ Pretest } & \multicolumn{2}{|c|}{ posttest } \\
\cline { 5 - 8 } & & pretest & posttest & $\max$ & $\min$ & $\max$ & $\min$ \\
\hline Esperimen & 38 & 2,96 & 15,49 & 4 & 0 & 17 & 8 \\
\hline
\end{tabular}

Berdasarkan Tabel 3, jumlah siswa yang mengikuti pretest- posttest kemampuan Kemampuan Representasi Matematis pada kelas esperimen yaitu 38 siswa. Rata-rata skor pretest adalah 2,96 dan rata-rata skor pretest adalah 15,49. Skor terendah dan tertinggi pretest 0 dan 4 dan skor terendah dan tertinggi posttes Kemampuan Representasi Matematis 8 dan 17. Sedangkan peningkatan rata-rata pretest- posttest adalah -9,513.

Berdasarkan jawaban yang diberikan siswa, secara umum siswa tidak memeiliki kemampuan awal yang berarti. Siswa yang mendapat nilai rendah, umumnya kurang melakukan usaha dengan tetap membiarkan lembar jawaban kosong. Dari hasil table 3.1, tanpak bahwa posttest kemampuan Kemampuan Representasi Matematis siswa secara rata-rata lebih tinggi dari rata-rata pretest, berarti bahwa ada peningkatan kemampuan Kemampuan Representasi Matematis siswa yang belajar menggunakan pembelajaran CMP.

Tes ini diberikan kepada kelompok eksperimen yang memperoleh pembelajaran CMP masalah dan kelompok kontrol yang memperoleh pembelajaran biasa/konvensional. Hasil Posttest Kemampuan Representasi Matematis dan penalaran dapat dilihat pada Tabel 3.2. 
Table 3.2 Hasil Posttest Kemampuan Representasi Matematis

\begin{tabular}{|c|c|c|c|c|c|c|c|}
\hline Kelas & Jumlah & Rata-rata & Rata-rata & \multicolumn{2}{|c|}{ Pretest } & \multicolumn{2}{|c|}{ posttest } \\
\cline { 5 - 8 } & & pretest & posttest & $\max$ & $\min$ & $\max$ & $\min$ \\
\hline Kontrol & 38 & 2,71 & 10,23 & 4 & 0 & 11 & 5 \\
\hline
\end{tabular}

Jumlah siswa yang mengikuti Posttest pada kedua kelas sampel yaitu masingmasing 38 siswa. Rata-rata skor Posttest untuk kelas eksperimen adalah 15,49 dan untuk kelas kontrol 10,23. Skor terendah pada kelas eksperimen adalah 8, skor tertinggi kelas esperimen 17 sedangkan skor terendah kelas kontrol 5 dan skor tertinggi adalah 11 .

Siswa yang belajaran melalui pembelajaran CMP memiliki skor rata-rata posttest lebih besar yaitu 15,49 , dari pada skor rata-rata pretes yaitu 2,96 . Hal ini menunjukkan bahwa ada perbedaan peningkatan antara rata-rata pretest-posttes kemampuan representasi matematis, pada pembelajaran CMP. skor terendah dan

Hal ini terjadi sebagai akibat dari pemberian pembelajaran CMP yang harus siswa selesaikan melalui proses saling tukar pikiran/sharing. Melalui diskusi siswa dapat mengemukakan ide dan pikirannya yang sesuai dengan tahap perkembangan kognitif mereka. Siswa terdorong untuk melakukan berbagai manipulasi, meskupun banyak diantara jawaban yang dikemukakan kurang berkaitan dengan masalah yang diberikan, tetapi ada hal penting yang tidak mereka sadari adalah mereka punya kekayaan ide, dinamis, membangun pengetahuan melalui suatu proses sebagaimana seorang ilmuwan menemukan suatu teori/dalil.

Dalam penelitian ini, peneliti membuat pembelajaran CMP. Pokok bahasan yang peneliti ambil adalah trigonometri. Dimana materi trigonometri merupakan materi yang sulit dipahami sebagian besar siswa. untuk mengetahui pretes kemampuan Kemampuan Representasi Matematis siswa yang berkenaan dengan trigonometri sebeleum pembelajaran di laksanakan. Jumlah siswa yang mengikuti pretest 38 siswa. Rata-rata skor pretest adalah 2,97. Skor terendah adalah 0 , skor tertinggi 6 .

Pembelajaran dalam kelompok kecil adalah salah satu model yang dikembangkan dalam pembelajaran matematika. Model pembelajaran ini sangat kondusif untuk terjadinya komunikasi berbagai arah antara siswa dalam kelompok belajar atau antara siswa lintas kelompok dalam kelasnya, begitu pula dapat terjalin komunikasi antara siswa dengan guru yang berperan sebagai fasilitator.

Tabel 3.1 dan 3.2 menunjukkan bahwa ada perbedaan peningkatan antara ratarata pretest-posttes kemampuan penalaran matematik, pada pembelajaran CMP. skor terendah dan Skor tertinggi siswa pada posttest adalah 0 dan 7, sedangkan skor terendah dan Skor tertinggi siswa pada pretest adalah 6 dan 13. Pembelajaran CMP berpengaruh pada kemampuan representasi matematisa dalam pembelajaran matematika. Table Independent samples test menunjukan bahwa perubahan posttest kemampuan Kemampuan Representasi Matematis pada kelas elsperimen adalah signifikan $(0,00<0,05)$. Walaupun kedua kelas perlakuan mengalami peningkatan posttest kemampuan representasi matematisa yang signifikan tetapi pada kelas eksperimen peningkatan kemampuan representasi matematisa lebih tinggi dibandingkan kelas posttest Kemampuan Representasi Matematis kelas kontrol. Hal ini menunjukan bahwa pembelajaran CMP yang saya berikan kepada kelas 
eksperimen cukup berpengaruh dalam meningkatkan kemampuan representasi matematis.

Pada Table independent samples test dapat dilihat $t_{\text {hitung. adalah 5,67 dengan }}$ probabilitas 0,000. Karena nilai probabilitas $0,00<0,05$, maka Ho ditolak atau dapat disimpulkan bahwa terdapat perbedaan kemampuan representasi matematis yang belajar menggunakan pembelajaran CMP dengan siswa yang mendapat pembelajaran biasa.

Hal mendukung hasil penelitian Widada: contextual learning media can effectively produce a pattern by which, with the teacheror friend guidance, the students can easily develop conjecture and perform vertical mathematization (Jumri, Widada, \& Herawaty, 2018). Juga, mathematical understanding of students taught using realistic mathematics learning was higher than those who taught using the conventional method (W. Widada et al., 2018). Kemampuan pemahaman konsep dan pemecahan masalah kelas eksperimen yang diberi pembelajaran dengan PMR adalah lebih baik dibandingkan dengan kemampuan pemahaman konsep dan pemecahan masalah kelas kontrol yang diberi pembelajaran matematika konvensional (Dewi Herawaty \& Rusdi, 2016). he students' mathematical communication abilities taught with realistic mathematics learning approaches are higher than those taught by traditional learning approaches. Also, the average ability of the students' mathematics communication learned using the ethnomathematics-oriented material was higher than those given nonethnomathematics (Wahyu Widada et al., 2018). Dengan demikain, kami yakin bahwa model pembelajaran CMP dapat meningkatkan kemampuan matematika siswa MI dengan baik.

\section{Simpulan}

Berdasarkan hasil analisis data, terdapat peningkatan yang signifikan kemampuan representasi matematis yang belajar menggunakan pembelajaran CMP. Dengan menerapkan pembelajaran CMP siswa semakin mudah memahami konsep dan prinsip matematika. Juga, peningkatan kemampuan representasi matematis yang belajar menggunakan pembelajaran CMP lebih tinggi dari siswa yang mendapat pembelajaran biasa.

\section{DAFTAR PUSTAKA}

Eddy, R. P. ., \& Berry, T. P. D. (2008). The Effects of Connected Mathematics Project 2 on Student Performance: Randomized Control Trial.

Fauzan, A., Slettenhaar, D., \& Plomp, T. (2002). Traditional Mathematics Education vs . Realistic Mathematics Education: Hoping for Changes. Proceedings of the 3rd International Mathematics Education and Society Conference. Copenhagen: Centre for Research in Learning Mathematics, 14.

Gravemeijer, K. (2008). RME Theory and Mathematics. Tools and Processes in Mathematics Teacher Education, 283-302.

Herawaty, D., Widada, W., Novita, T., Waroka, L., \& Lubis, A. N. M. T. (2018). 
Students' metacognition on mathematical problem solving through ethnomathematics in Rejang Lebong, Indonesia. Journal of Physics: Conference Series, 1088. https://doi.org/10.1088/1742-6596/1088/1/012089

Herawaty, Dewi, \& Rusdi, R. (2016). Increased Capacity Of The Understanding Of The Concept And The Ability To Solve Problems Through The Implementation Of The Model Of Teaching Mathematics Realistic Based On Cognitive Conflict Students. Journal of Mathematics Education (Infinity), 5(2), 109-120. https://doi.org/10.22460/infinity.v5i2.217

Jumri, R., Widada, W., \& Herawaty, D. (2018). Improving the Innovation of Mathematics Education Undergraduate through Cooperative Learning. International Journal of Science and Research (IJSR), 7(2), 2016-2019. https://doi.org/10.21275/ART201818

Lappan, G., Fey, J. T., Fitzgerald, W. M., Friel, S. N., Phillips, E. D., Glenview, I., \& Needham, M. (2002). Getting to know Connected mathematics. New Jersey: Prentice Hall. Retrieved from http://enrollment.pps.k12.or.us/.docs/pg/400/rid/13114/f/GettingToKnowCM P1.pdf

Phillips, E. (2003). Connected Mathematics Project. Michigan State University: Michigan State University.

Ubiratan D'ambrosio. (1985). FLM Publishing Association Ethnomathematics and Its Place in the History and Pedagogy of Mathematics. Source: For the Learning of Mathematics, 5(1), 44-48.

Widada, W., Herawaty, D., \& Lubis, A. N. M. T. (2018). Realistic mathematics learning based on the ethnomathematics in Bengkulu to improve students' cognitive level. Journal of Physics: Conference Series, 1088. https://doi.org/10.1088/1742-6596/1088/1/012028

Widada, Wahyu. (2004). Pendekatan Pembelajaran Matematika Berbasis Masalah. Surabays: Unipa Press.

Widada, Wahyu. (2016a). Profile Of Cognitive Structure Of Students In Understanding The Concept Of Real Analysis. Journal of Mathematics Education (Infinity), 5(2), 83-98. https://doi.org/10.22460/infinity.v5i2.215

Widada, Wahyu. (2016b). Sintaks Model Pembelajaran Matematika Berdasarkan Perkembangan Kognitif Peserta Didik. Jurnal Pendidikan Matematika Raflesia, 1(2), 146-154.

Widada, Wahyu, Herawaty, D., Falaq, A., Anggoro, D., Yudha, A., \& Hayati, M. K. (2019). Ethnomathematics and Outdoor Learning to Improve Problem Solving Ability. Advances in Social Science, Education and Humanities Research, Volume 295, 295(ICETeP 2018), 13-16.

Widada, Wahyu, Herawaty, D., Yanti, D., \& Izzawati, D. (2018). the Student Mathematical Communication Ability in Learning Etnomathematics Orieted Realistic Mathematics. International Journal of Science and Research (IJSR), 7(9), 881-884. https://doi.org/10.21275/ART20191277

Zulkardi. (1999). How to Design Mathematics Lessons based on the Realistic Approach? RME, Realistic Mathematics Education. Retrieved from www.reocities.com/ratuilma/rme.html 